Article

\title{
Life Cycle Assessment of Gilthead Seabream (Sparus aurata) Production in Offshore Fish Farms
}

\author{
Benjamín García García ${ }^{1, *}$, Caridad Rosique Jiménez ${ }^{2}$, Felipe Aguado-Giménez ${ }^{3}$ and \\ José García García ${ }^{1}$ \\ 1 IMIDA, Calle Mayor s/n, 30150 Alberca Las Torres, Murcia, Spain; jose.garcia21@carm.es \\ 2 Departamento Mixto, Universidad de Murcia, Edificio C, Campus de Espinardo, 30100 Espinardo, Murcia, \\ Spain; crosique@um.es \\ 3 Estación de Acuicultura Marina (IMIDA), Puerto de San Pedro del Pinatar, 30740 San Pedro del Pinatar, \\ Murcia, Spain; felipe.aguado@carm.es \\ * Correspondence: benjamin.garcia@carm.es; Tel.: +34-968-366754
}

Academic Editor: Shelley Burgin

Received: 6 September 2016; Accepted: 21 November 2016; Published: 25 November 2016

\begin{abstract}
Life cycle assessment is used in this study to evaluate the potential environmental impacts of producing gilthead seabream in an offshore sea farm exposed to storms in the Spanish Mediterranean Sea. The farming methods used can be considered as "basic" since no centralized or automatic food distribution system exists and there is no control system. This study aims to identify the main hotspots under these conditions and to propose and compare viable alternatives to them. Contribution analysis found that the component of the system with the greatest potential environmental impact ( $48 \%$ of the overall impact) was fish feed, especially the raw material used. Other contributory factors were the fuel consumed by the vessels operating in the farm (35\%), the dumping of $\mathrm{N}$ and $\mathrm{P}$ in the environment due to the metabolism of the fish (12\%), the cages and their anchorage system (5\%). A sensitivity analysis showed that a significant reduction in potential environmental impact can be achieved by increasing feeding efficiency. Feed formulation in raw materials is also an important factor and could serve to diminish overall adverse effects. A balance needs to be found between productive performance (growth, survival and feed conversion rate), feed price and its influence on production costs and the overall environmental consequences.
\end{abstract}

Keywords: environmental impact; feed; life cycle assessment; offshore fish farm; Sparus aurata

\section{Introduction}

Eighty five percent of aquacultural production of gilthead seabream (Sparus aurata; hereafter seabream) in Europe and other countries mostly takes place in floating cages [1]. Production in 2013 was estimated to be 179,924 tonnes [2], while the main European producers are Greece (42\%), Turkey (23\%) and Spain (9\%). Just over 93\% of the seabream produced along the Spanish Mediterranean and Atlantic coasts comes from offshore cages, which are exposed to storms and strong hydrodynamic conditions. These facilities are located on detrital bottoms, at a depth of 30-50 m and away from sensitive habitats, such as those of Posidonia oceanica meadows and maerl beds [3-6].

Offshore farming facilities (cages and anchoring) are characterized by their flexibility, which reduces stress on the structures. Cages are circular for a better tolerance of waves and currents [7]. While such facilities have demonstrated their technical and economic viability for fish ongrowing, the harsh offshore conditions limit the implementation of centralized systems for automatic programmed feeding and control systems to prevent feed losses.

It is well documented that most of the adverse environmental impacts associated with fish farming are restricted to the immediate vicinity of the farms and are related with the release of organic wastes 
derived from feed, both in dissolved (ammonium, urea, etc.) and particulate (uneaten feed and feces) forms [8-16].

Dissolved wastes are quantitatively much more plentiful than particulate ones $[10,17,18]$. Nevertheless, in Mediterranean offshore ongrowing systems, it has been demonstrated that dissolved wastes are potentially less harmful than solid, since the former are quickly dispersed by local currents [19-22]. For this reason, most of the efforts regarding local environmental impact have focused on the seabed and benthic communities [3,11,23-31].

However, current knowledge about other environmental impacts at a global scale (abiotic depletion, global warming, acidification, cumulative energy demand, etc.) is still very far from the level that exists for different aquaculture systems (e.g., net-pen, floating-bar, flow-through tank and recirculation systems) in salmonids [32-34]. As suggested by some authors [35], to better understand the consequence of fish farms on the environment, it is important to determine the impact on the immediate surroundings and on a global scale.

An integrative approach, considering both impacts at the local and global scale, is necessary to better understand the consequences of fish farming on the natural environment [35].

The first significant intensive integral production of seabream off the Spanish Mediterranean coast began in 1984 (Murcia, SE Spain; [36]), and floating marine cage fish farms have existed since then in this region [37]. The sector has developed and consolidated and currently comprises 10 facilities in the open sea. The province of Murcia is amongst the largest producers of seabream and seabass (Dicentrarchus labrax; hereafter seabass) in Spain, with an average production in the past five years of about 10 thousand tonnes ( $28 \%$ of the total Spanish production). Hence, the offshore production of seabream as described in this study can be considered representative of this activity in a more global context.

We apply life cycle assessment (LCA) to the production of seabream in a basic offshore fish farm (BOFF) as described above. The objectives were to: (1) describe a basic facility lacking any centralized or automatic feed distribution system or control system in an area exposed to strong hydrodynamic conditions, which may be taken to be representative of cage farming operations in Spain; (2) identify the components of the system that most contribute to the environmental impacts associated with the activity; and (3) analyze viable alternatives for reducing environmental impacts with the aim of improving environmental management at the farm level.

\section{Material and Methods}

Life cycle assessment (LCA) is a standardized method [38,39] designed to collect and evaluate the inputs and outputs and the potential environmental impacts associated with a product system, from the acquisition of raw materials or their generation from natural resources to their final disposal. Also known as cradle-to-grave analysis, LCA includes the quantification and evaluation of consumed resources and emissions to the environment at all stages of the life cycle, from the extraction of raw material to waste disposal [40]. LCA consists of four stages: (1) the definition of the objective and scope; (2) inventory; (3) impact analysis; and (4) interpretation. Such an analysis allows management of the most important impacts throughout a product's life cycle.

\subsection{Objective, Scope and Functional Unit}

The aim of this study was to characterize the potential environmental impacts and their causes associated with the aquacultural production of seabream up to a commercial size of $450 \mathrm{~g}$. The study was carried out in a fish farm under offshore conditions in the Mediterranean with an annual production of 1000 tonnes. The farm, as described above, is considered "basic" and representative of those operating off the Spanish coasts, as it has no centralized feed distribution system, no automatic distribution system and no control system. This study aims to identify the main hotspots existing under these conditions and to propose and compare alternatives for seabream aquaculture. 
The functional unit is defined as 1 tonne of seabream at the fish farm gate and is used as a reference unit to which all environmental impacts are quantified. Such a measure of live-weight fish at the farm gate is the functional unit commonly used in this type of study [41,42].

The different subsystems that can be established for the LCA of marine fish production may be based on the value chain, in such a way that LCA can be clearly related with an economic and financial analysis. The subsystems are: (1) production, which includes the hatching and nursing activities that provide the juveniles to start the process and the ongrowing of the same up to marketable size; (2) marketing, which encompasses classification and packaging, distribution and sale and consumption; and (3) the manufacture of the fish feed necessary for nursing and ongrowing. In this first study, LCA includes two subsystems: seabream ongrowing and manufacture of feed (Figure 1).

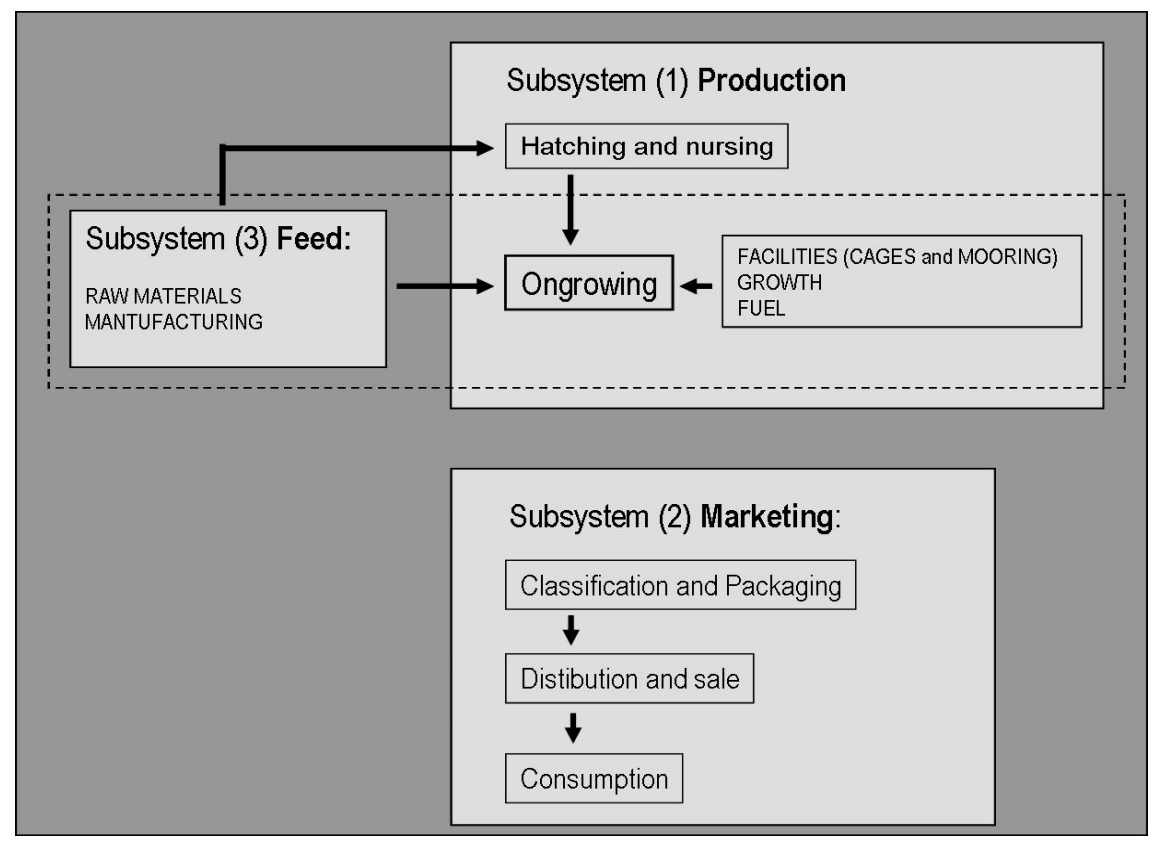

Figure 1. Subsystems for the LCA of marine fish production. The dashed line shows the scope of LCA of gilthead seabream production in offshore fish farms.

The hatching and nursing subsystem is an important phase in the production of fish, but in our scenario area, there are no companies dedicated to this purpose; so, we have no specific data. Due to its characteristics, it is an entirely different and more complex process (onshore facility, maintenance of the reproductive stock, production of phytoplankton and zooplankton to feed the larvae, etc.), and as in other LCAs on Mediterranean fish species [43], it has not been included. However, our intention in the future is to try to overcome such difficulties and address all of the subsystems involved in seabream production, from hatchery to consumption.

In the LCA of different products, particularly those related to the production of marine fish, it is common to ignore infrastructure since it is assumed to have no significant environmental impacts [33,44], because of the long periods of amortization. However, we have made an effort to expand current knowledge on the contribution of the infrastructure to the total impact of the system following the recommendations of some authors [45]. Offshore fish ongrowing facilities include elements with different periods of amortization, some of short duration. Therefore, not only have we taken into account operations related to the production cycle in offshore facilities (such as feed, emissions due to fish metabolism and fuel consumed by vessels), but also the cages themselves, including their anchoring systems, although boats have not been considered. For the fish feed, we have considered the manufacturing process and raw material, but related infrastructures are not taken into account. 


\subsection{Description of the System and Its Components, Data Collection and Life Cycle Inventory}

To define a basic offshore fish farm (BOFF), we made confidential surveys and visited companies located along the coast of the province of Murcia (Región de Murcia, SE Spain). We also consulted companies manufacturing and selling the infrastructure needed for offshore cage fish farming (floating cages, ropes, buoys, mooring, etc.) and also fish feed producers. Official documents from the Service of Fishing and Aquaculture Service of the Autonomous Government of Murcia Region and data available in the literature were also consulted $[1,7,46-49]$. The basic farm that is evaluated in this study has a production of $1000 \mathrm{t} \cdot \mathrm{year}^{-1}$ of seabream. The nearest harbor is located about $5 \mathrm{~km}$ away, and the depth in the facilities is $40 \mathrm{~m}$. The site is exposed to prevailing winds (from NE and SW); $80 \%$ of the waves have a significant height of $0.4-1.2 \mathrm{~m}$, but waves with significant heights of around $10 \mathrm{~m}$ have been recorded in the area, but with a low $(<0.1 \%)$ probability [50].

The size of the farms take into consideration that juveniles entering the cages weigh $12 \mathrm{~g}$ and are harvested when they reach $450 \mathrm{~g}$ after 18 months on average. Each cage produces an average of 90 tonnes, and the mortality rate is $10 \%$. Extruded feed is distributed by cannons from a boat that visits all of the cages of the fish farm. The feed conversion rate (FCR = feed supplied / biomass increase) was 2.

The analyzed system is defined with the following components and sub-components: FACILITIES which includes the CAGE (FLOATING RING and NET) and MOORING; and OPERATIONS throughout the production cycle, which includes GROWTH (responsible for the emissions of N and P due to the metabolism of the fish); FEED, in which RAW MATERIALS and MANUFACTURING are distinguished; and TRANSPORT (from the feed factory to the farm operating harbor); and FUEL consumed by the vessels operating in the farm and their emissions into the atmosphere (Figure 1).

\subsubsection{Facilities}

The various materials used in the FACILITIES are grouped into CAGE (FLOATING RING and NET) and MOORING.

\section{CAGE}

Twenty cages are needed for the annual production of 1000 tonnes. The cages diameter is $25 \mathrm{~m}$. Each consists of two concentric floating rings of high density polyethylene $325 \mathrm{~mm}$ in diameter, $28 \mathrm{~kg} \cdot \mathrm{m}^{-1}$ ), filled with expanded polystyrene foam (density $10 \mathrm{~kg} \cdot \mathrm{m}^{-3}$ ) and a perimeter handrail of $90 \mathrm{~mm}$ in diameter $\left(3.14 \mathrm{~kg} \cdot \mathrm{m}^{-1}\right)$, held to the two floating rings by 40 pieces of polyethylene (20 kg per unit). Each cage has a 110-kg structure of polyethylene to support the top net, which is used to prevent birds from catching the fish.

\section{NET}

The NET is a 16 meter high nylon bag with a mesh size that changes according to the size of the fish. For simplification, we consider the longest, with $27-\mathrm{mm}$ mesh and which weighs $0.5 \mathrm{~kg} \cdot \mathrm{m}^{-2}$. The net is attached to the polyethylene ring with a propylene rope and is ballasted at the bottom. The top nylon net has a mesh size of $50 \mathrm{~mm}$.

\section{MOORING}

The 20 cages are grouped into two rows bound together by ropes joined to the three main ropes, two external ones and one in the middle, according to the scheme in Figure 2. Flotation buoys can be of different volumes, and we considered one with an average value of $1100 \mathrm{~L}$, manufactured in polyethylene and filled with polyurethane. Their distribution in the installation is also shown in Figure 2.

The mooring system works with 28 cast iron anchors (1000 kg per unit), as shown in Figure 2. A 20-m chain $\left(36 \mathrm{~kg} \cdot \mathrm{m}^{-1}\right)$ extending from each anchor is attached to a 56-mm rope, and a PVC depth buoy ( $3.62 \mathrm{~kg}$ per unit) is attached. All of the metal components used to attach the mooring elements, 
such as rope guards, distribution plates, swivels, shackles, etc., are also included. The lease containing the facility is marked by four perimeter buoys (like those described above) moored to concrete blocks (4000 kg per unit).

The various elements have different amortization periods: the polyethylene structure of the cage lasts 10 years; the net 5 years; and for the anchoring, we considered different average values based on the materials: 10 years for the buoys and 5 years for ropes and metal mooring parts (shackles, thimbles, etc.); and 25 years for anchors, chains and concrete blocks.

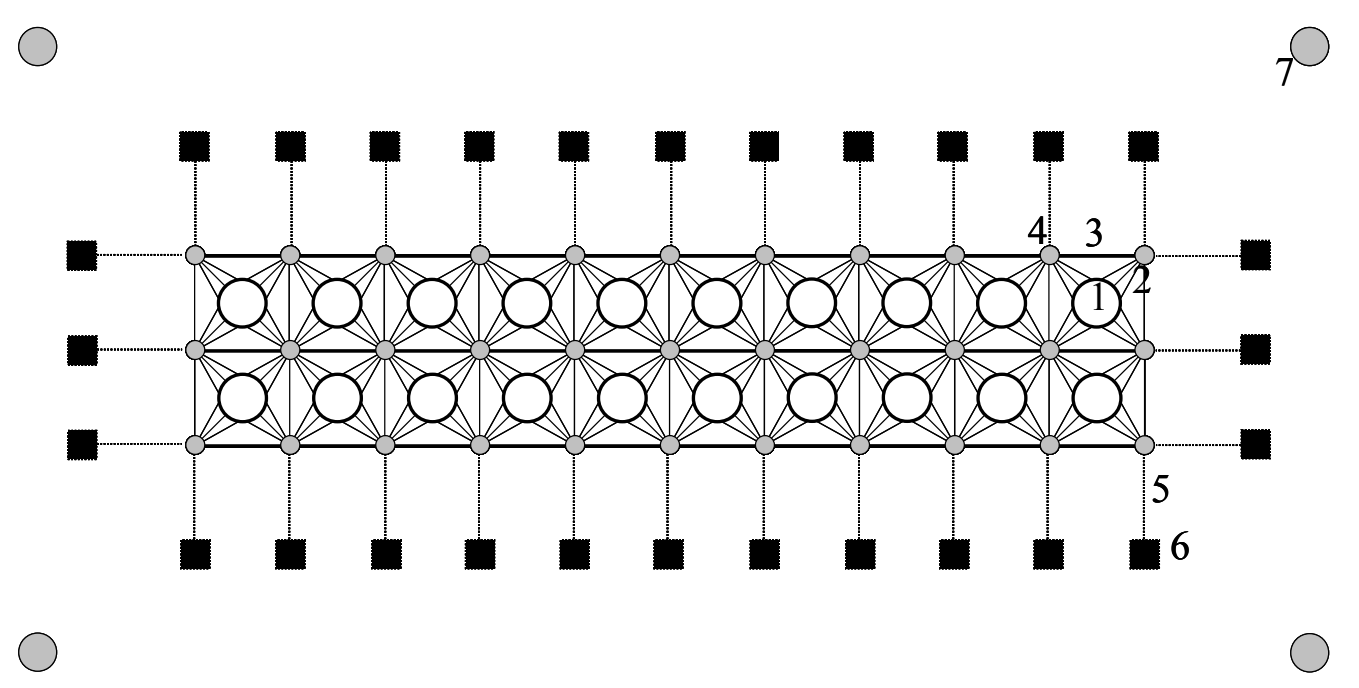

Figure 2. Schema of the basic offshore fish farm for the production of 1000 tonnes of gilthead seabream. 1: Cage; 2 : union rope between the cage and the main rope; 3 : main rope; 4 : surface buoys; 5 : rope and chain anchor; 6: anchor; 7: marker buoys of the fish farm.

Table 1 shows the materials expressed in $\mathrm{kg}$ of the BOFF facilities to produce $1000 \mathrm{t} \cdot \mathrm{year}^{-1}$ of seabream. To assess the environmental impact of the various elements making up the facilities, reference flows of various installation materials are calculated considering the useful life of the materials and the duration of the production cycle (Table 2). The calculation is made according to the following formula:

$$
\mathrm{Mr}=(\mathrm{Mi} \times \mathrm{PC}) /(\mathrm{UL} \times 1000)
$$

where $\mathrm{Mr}$ is the amount of material $(\mathrm{kg})$ from the BOFF facilities in relation to the functional unit (1 tonne of seabream), Mi is the amount of material $(\mathrm{kg})$ used in BOFF for the production of $1000 \mathrm{t} \cdot$ year $^{-1}$ of seabream, UL is the useful life of each material in months and PC is the duration of the production cycle measured in months (18 months).

Table 1. Materials expressed in $\mathrm{kg}$ of the facilities of the basic offshore fish farm (BOFF) for the production of $1000 \mathrm{t} \cdot$ year $^{-1}$ of seabream.

\begin{tabular}{ccccc}
\hline Materials & FLOATING RING & NET & MOORING & Total \\
\hline Polyethylene & $111,097.11$ & & 3718.00 & $114,815.11$ \\
Polystyrene & 1604.44 & & & 1604.44 \\
Nylon & & $13,738.10$ & & $13,738.10$ \\
Polypropylene & & 1330.00 & $14,328.30$ & $15,658.29$ \\
Polyurethane & & 473.00 & 473.00 \\
Polyvinylchloride & & 73.36 & 73.36 \\
Cast iron & & $28,000.00$ & $28,000.00$ \\
Steel, chromium steel & & 6682.70 & 6682.70 \\
Steel, low-alloyed & & $22,912.00$ & $22,912.00$ \\
Concrete block & & $16,000.00$ & $16,000.00$ \\
\hline
\end{tabular}


Table 2. Inputs and outputs for the production of $1 \mathrm{t}$ live-weight of gilthead seabream in the basic offshore fish farm (BOFF).

\begin{tabular}{|c|c|c|c|}
\hline \multicolumn{4}{|c|}{ Input FACILITIES $\left(\mathrm{kg} \cdot \mathrm{t}^{-1}\right)$} \\
\hline Materials & FLOATING RING & NET & MOORING \\
\hline Polyethylene & 16.6646 & & 0.5577 \\
\hline Polystyrene & 0.2407 & & \\
\hline Nylon & & 4.1214 & \\
\hline Polypropylene & & 0.3990 & 4.2985 \\
\hline Polyurethane & & & 0.0710 \\
\hline Polyvinylchloride & & & 0.0220 \\
\hline Cast iron & & & 1.6800 \\
\hline Steel, chromium steel & & & 2.0048 \\
\hline Steel, low-alloyed & & & 1.3747 \\
\hline Concrete block & & & 0.9600 \\
\hline Transport (kg km) & 500 & 500 & 500 \\
\hline \multicolumn{2}{|c|}{$\begin{array}{l}\text { Input FEED (RAW MATERIALS, } \\
1 \mathrm{t} \text { feed }\left(\mathrm{kg} \cdot \mathrm{t}^{-1} \text { feed) FCR: } 2\right.\end{array}$} & \multicolumn{2}{|c|}{$\begin{array}{l}\text { Output FUEL }\left(\mathrm{kg} \cdot \mathrm{t}^{-1}\right) \\
\text { emissions to air; emissions factors [51] }\end{array}$} \\
\hline Wheat & 140 & $\mathrm{CO}_{2}$ & 1409.697 \\
\hline Wheat gluten meal & 130 & $\mathrm{CO}$ & 3.555 \\
\hline Fish meal & 200 & $\mathrm{NO}_{\mathrm{x}}$ & 26.216 \\
\hline Soybean meal & 220 & NMVOC & 1.155 \\
\hline Corn gluten meal & 100 & $\mathrm{CH}_{4}$ & 0.049 \\
\hline Fish oil & 80 & VOC & 1.200 \\
\hline Rapeseed oil & 50 & $\mathrm{PM}_{10}$ & 0.622 \\
\hline Soybean oil & 50 & $\mathrm{SO}_{2}$ & 2.444 \\
\hline \multirow{2}{*}{$\begin{array}{l}\text { Vitamins and minerals } \\
\text { Feed plant transport } \\
(\mathrm{t} \cdot \mathrm{km})\end{array}$} & 30 & $\mathrm{~N}_{2} \mathrm{O}$ & 0.036 \\
\hline & 500 & $\mathrm{NH}_{3}$ & 0.004 \\
\hline $\begin{array}{l}\text { Fish farm transport } \\
\qquad(\mathrm{t} \cdot \mathrm{km})\end{array}$ & 500 & & \\
\hline \multicolumn{2}{|c|}{ Input FEED (MANUFACTURING) [44] } & \multirow{2}{*}{\multicolumn{2}{|c|}{$\begin{array}{c}\text { Output FEED (MANUFACTURING) [44] } \\
\text { Output GROWTH }\left(\mathrm{kg} \cdot \mathrm{t}^{-1} \text { ); }\right. \\
\text { Emissions to Sea Water }\end{array}$}} \\
\hline \multicolumn{2}{|c|}{ Input FUEL $\left(\mathrm{kg} \cdot \mathrm{t}^{-1}\right)$} & & \\
\hline Diesel & 444.33 & Total N & 119.59 \\
\hline Lubricating oil & 1.26 & Total P & 5.93 \\
\hline
\end{tabular}

FCR: food conversion rate; Nox: nitrogen oxides; NMVOC: non-methane volatile organic compounds; VOC: volatile organic compounds.

The data in relation to the extraction of raw materials, processing, manufacturing and transportation come from the Ecoinvent 3.1 database (compiled October 2014).

\subsubsection{Operations in the Production Cycle}

\section{FEED}

The diet of the seabream is mostly composed of extruded feed, mainly provided by four companies. These feeds are made primarily from wheat, fish meal, soybean meal, maize gluten meal, wheat gluten meal, fish oil, rapeseed oil, soya oil, a premix of minerals and vitamins and amino acids. The raw materials' composition in kg per 1 tonne of feed are shown in Table 2.

For this study, we establish a standard feed, based on the information provided by fish feed producers and confidential consultations. Furthermore, information available in the literature for other marine species was reviewed $[43,44,52]$. This standard feed (FEED) is approximately $43 \%$ protein and $22 \%$ lipid.

Data related to the agricultural production of the RAW MATERIALS, as well as transformation and transport to the fish feed factory, were taken from Agri-footprint 2.0 mass allocation databases 
(October 2015), except for the fish meal and fish oil data, which are not available and were taken from the LCA Food DK (Denmark) database. In this database, however, these raw materials follow a consequential model based on the assumption that the production of fish oil avoids the use of rapeseed oil, and so, they are not assigned any environmental load. Therefore, the data were modified, considering the meal and fish oil as by-products with an allocation of masses. The LCA Food DK database considers that $1 \mathrm{~kg}$ of fishmeal and $0.208 \mathrm{~kg}$ of fish oil can be obtained from $4.66 \mathrm{~kg}$ fresh weight of fish. For this reason, the environmental load involved in these processes is expressed proportionally, i.e., $82.78 \%$ for the fishmeal and $17.22 \%$ for the oil.

The premix (minerals and vitamins) and amino acids are not available in the databases and have not been taken into account. However, they only represent $3 \%$ of the total. For the feed manufacturing process (MANUFACTURING), data provided by [44] were used. TRANSPORT involves the transport of the feed by truck to the harbor associated with the farm from the factory located $500 \mathrm{~km}$ away.

\section{GROWTH}

GROWTH reflects $\mathrm{N}$ and $\mathrm{P}$ emissions due to the metabolism of the food during the entire production cycle. The gross metabolic waste is calculated using a nutritional approximation based on the following equation: $\mathrm{C}=\mathrm{G}+\mathrm{E}+\mathrm{F}$, where $\mathrm{C}$ is the $\%$ in dry matter of $\mathrm{N}$ or $\mathrm{P}$ in the ingested food, $G$ is the quantity of nutrients retained for growth, $E$ are losses through excretion and $F$ are losses through the feces $[10,17,18,29,53-55]$. To calculate the waste output, we applied the model for gilthead seabream proposed by [10], the average apparent digestibility coefficient of three commercial extruded feeds for seabream from [56]) and an FCR of 2 obtained from confidential surveys of fish farming companies (Table 2).

FUEL

BOFF has 4 vessels: one inflatable boat with a 200-hp engine, one monohull boat of $400 \mathrm{hp}$, one catamaran with $2 \times 100 \mathrm{hp}$ and another catamaran with $2 \times 310 \mathrm{hp}$. From the annual consumption, we estimated that the fuel consumption to produce $1 \mathrm{t}$ of seabream (functional unit) is $444.33 \mathrm{~kg}$ of diesel and $1.26 \mathrm{~kg}$ of lubricant. The data relating to the extraction of raw materials, processing, manufacturing and transport come from the Ecoinvent 3.1 database (compiled October 2014), and emissions due to the consumption of diesel were estimated using data for fishing vessels [51] (Table 2).

\subsection{Evaluation of the Impact of the Life Cycle}

Of the two methodological LCA approaches commonly used, attributional LCA and consequential LCA [34], we used the attributional approach, which focuses on a description of the product system and its environmental exchanges using average data from a retrospective point of view. For quantification of the impacts associated with the studied system, we use a midpoint approach, CML, in which the results of the inventory of the life cycle are characterized into categories of relevant environmental impact and expressed in reference units to indicate the potential contribution to specific global environmental impacts.

The impact indicator categories were calculated based on the CML methodology (v. 3.02, 2013) developed by the Institute of Environmental Sciences, University of Leiden [40] and SimaPro 8.04 software (PRé Consultants: Amersfoort, The Netherlands.). This methodology has been used in numerous seafood LCAs for both fishing and aquaculture [32,33,44,52,57-62]. The impact categories used in this study to determine the potential impact are abiotic depletion (AD), global warming (GW), ozone layer depletion (OLD), photochemical oxidation (PO), acidification (A) and eutrophication (E). Cumulative energy demand (CED) was also used (SimaPro 8.04). GW, A, E and CED are the most commonly-used impacts in LCAs in aquaculture, while the evaluation of impacts that manifest themselves at a regional level, such as loss of biodiversity amongst others, has not yet been developed [42]. 


\subsection{Interpretation of the Results}

\subsubsection{Uncertainty Analysis}

To determine the reliability of the evaluation model of the different impact categories in the BOFF, a Monte Carlo uncertainty analysis was carried out using the inventory data [63]. For this, we used the SimaPro 8.02 software, carrying out 1000 simulations with a $95 \%$ confidence interval. For each category of environmental impact, the software estimated the average, the standard deviation, the coefficient of variation, $95 \%$ confidence intervals and the standard error of the mean.

To determine the reliability of the differences in the different indicator impact categories for the alternatives, we also used a Monte Carlo test with SimaPro 8.02 (carrying out 1000 simulations from the inventory data with a 95 confidence interval), which estimates the probability of $A \geq B$, where $A$ is the value of the environmental impact category obtained in the model for the BOFFF and $B$ the value obtained for each of the analyzed alternatives.

\subsubsection{Contribution Analysis}

This analysis calculates the contribution of different factors, or components of the system, to each of the impact category indicators used in the study. Two qualitative indexes that are useful in the presentation and discussion of the results are also used. The overall contribution of each component of the system to all of the impact categories (OC) is expressed as a percentage. This is calculated as the sum of contributions of each component of the system to all impact categories divided by the number of impact categories. Likewise, the overall contribution of each raw material contained in the feed and in relation to RAW MATERIAL (sub-component of the system) was calculated. The global reduction of impacts (GRI) is calculated as a percentage of the sum of the reductions of impacts for each alternative studied in relation to potential impacts found in the BOFF $(100 \%)$.

\subsubsection{Sensitivity Analysis}

Four possible alternatives to the model developed for the BOFF were evaluated. These alternatives, which reflect realistic scenarios that might be developed in the seabream production sector, are:

Alternative 1: 15\% decrease in FCR.

Alternative 2: $15 \%$ decrease in the FCR and 30\% decrease in fuel consumption (70\% FUEL).

Alternative 3: a diet rich in maize gluten meal (40\%).

Alternative 4: all of the above factors.

\section{Results and Discussion}

\subsection{Uncertainty Analysis (Monte Carlo)}

The uncertainty analysis shows the reliability of the model to evaluate the potential environmental impacts of the fish farm (Table 3). The highest coefficient of variation was recorded for OLD $(27.56 \%)$, so that the confidence intervals are wide at $95 \%$. On the other hand, the coefficients of variation were low for E (0.36\%), GW (2.53\%), A (5.60\%) and PO (7.43\%) and around $10 \%$ for $\mathrm{AD}(12.90 \%)$ and CED $(11.47 \%)$. The coefficient of variation of OLD may be due to the high variability of the inventory data regarding air emissions of CFCs, the origin of which is mainly the production of energy and fuel. Whatever the case, OLD is the least reliable environmental impact category in the present study. 
Table 3. Monte Carlo uncertainty analysis of the potential environmental impact categories (PEIC) in the basic offshore fish farm (BOFF); $1 \mathrm{t}$ live-weight of gilthead seabream.

\begin{tabular}{ccccccc}
\hline PEIC & Equivalency Unit & Mean & SD & CV (\%) & $\mathbf{9 5 \% ~ C I ~}$ & SEM \\
\hline $\mathrm{AD}$ & $\mathrm{kg} \mathrm{Sb}-\mathrm{eq}$ & 0.00165 & 0.00021 & 12.90 & $0.00125-0.00210$ & 0.000067 \\
$\mathrm{GW}$ & $\mathrm{kg} \mathrm{CO}_{2}$-eq & 7124 & 180 & 2.53 & $6796-7487$ & 5.69 \\
$\mathrm{OLD}$ & $\mathrm{kg} \mathrm{CFC}-11-\mathrm{eq}^{\mathrm{m}}$ & 0.00130 & 0.00035 & 27.56 & $0.00089-0.00217$ & 0.000011 \\
$\mathrm{PO}$ & $\mathrm{kg} \mathrm{C}_{2} \mathrm{H}_{4}$-eq & 1.12 & 0.08 & 7.43 & $1.01-1.33$ & 0.003 \\
$\mathrm{Ag}$ & $\mathrm{kg} \mathrm{SO}_{2}$-eq & 38.46 & 2.15 & 5.60 & $35.64-43.82$ & 0.07 \\
$\mathrm{E}$ & $\mathrm{kg} \mathrm{PO}_{4}$-eq & 81.79 & 0.36 & 0.44 & $81.18-82.64$ & 0.01 \\
$\mathrm{CED}$ & $\mathrm{GJ}$ & 98.12 & 11.25 & 11.47 & $79.51-121.98$ & 0.36 \\
\hline
\end{tabular}

AD: abiotic depletion; GW: global warming; OLD: ozone layer depletion; PO: photochemical oxidation; A: acidification; E: eutrophication; CED: cumulative energy demand. SD: standard deviation; CV: coefficient of variation; $\mathrm{CI}$ : confidence intervals; SEM: standard error of mean.

\subsection{Contribution Analysis}

The component of the system that globally contributed the most to the environmental problem (OC) was FEED (Figure 3) at 48\%, followed by FUEL (35\%), GROWTH (12\%) and FACILITIES (5\%). In the LCA on fish production in different aquaculture systems, both at sea and on land, feed is mainly responsible for the associated impacts [32-34,43,44,60].

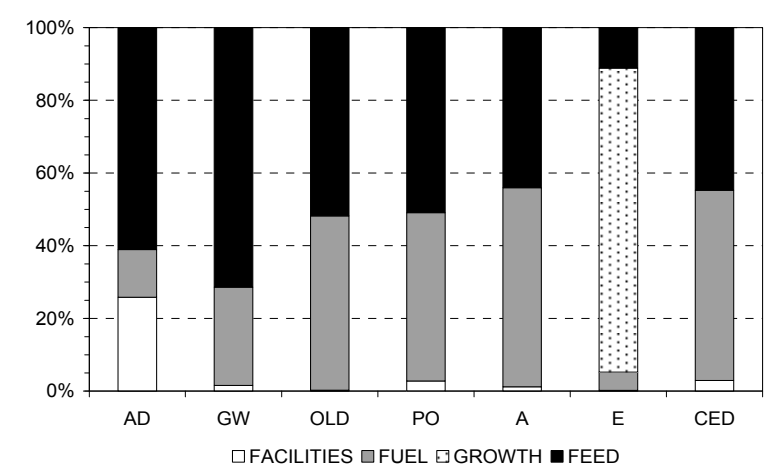

Figure 3. Contribution of system components to different impact categories. AD: abiotic depletion; GW: global warming; OLD: ozone layer depletion; PO: photochemical oxidation; A: acidification; E: eutrophication; CED: cumulative energy demand.

\subsubsection{FACILITIES}

The contribution of the FACILITIES to most of the impact categories is generally low (Figure 3), except AD, which represents $26 \%$. MOORING is the sub-component of FACILITIES (Figure 4) that represents the greatest contribution to $\mathrm{AD}(92 \%)$ and OLD $(58 \%)$, while CAGE (RING + NET) is responsible for the highest contributions to GW (69\%), PO (64\%), A (63\%) and E (57\%).

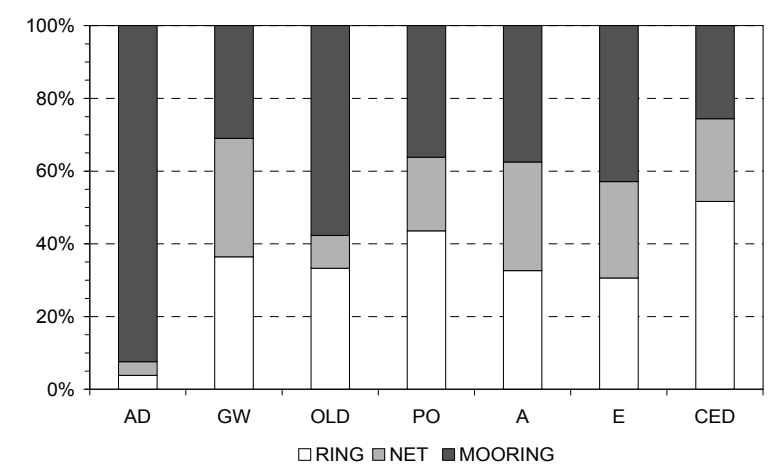

Figure 4. Contribution of FACILITIES components to the environmental impact potentials. 
Many authors assume that infrastructure makes a negligible contribution to the life cycle impacts of fish farming systems $[32,33,44]$ due to the long life (more than 20 years) estimated for the infrastructure and equipment [44].

In land-based fish farming systems, the contribution of infrastructure to the various impact categories is low in relation to other components of the system, such as energy or feed. This has been reported in the case of seabass in traditional raceways and cascade raceways [60], rainbow trout (Oncorhynchus mykiss) in freshwater raceways, turbot (Scophthalmus maximus) in recirculating systems [43] and salmon (Salmo salar) in a land-based saltwater flow-through system and freshwater recirculating system [32]. In sea farming systems close to the coast, the contribution of the infrastructure in the impact categories has been found to be low. This has also been reported for sea bass in sea cages [43] and salmon in a conventional marine net-pen system and marine floating bag system [32]. In the present study, the infrastructure was also seen to have a small impact in the different categories of environmental impact. However, it played an important role in $\mathrm{AD}$ (Figure 3), primarily due to the metallic elements used in MOORING (Figure 4).

\subsubsection{FEED}

FEED is the component of the system that generally represents the greatest overall contribution to the various impact categories, except in the case of $\mathrm{E}$, when it is only $11 \%$ (Figure 3). Its contribution to GW $(71 \%)$ is of particular note. Among the subcomponents of FEED, TRANSPORT (from the factory to the feed installation) made a very low contribution to the impact categories, being almost negligible. RAW MATERIALS (Figure 5), on the other hand, was the sub-component that generally had a greater impact, with contribution values ranging from $51 \%$ (AD) to $90 \%$ (CED).

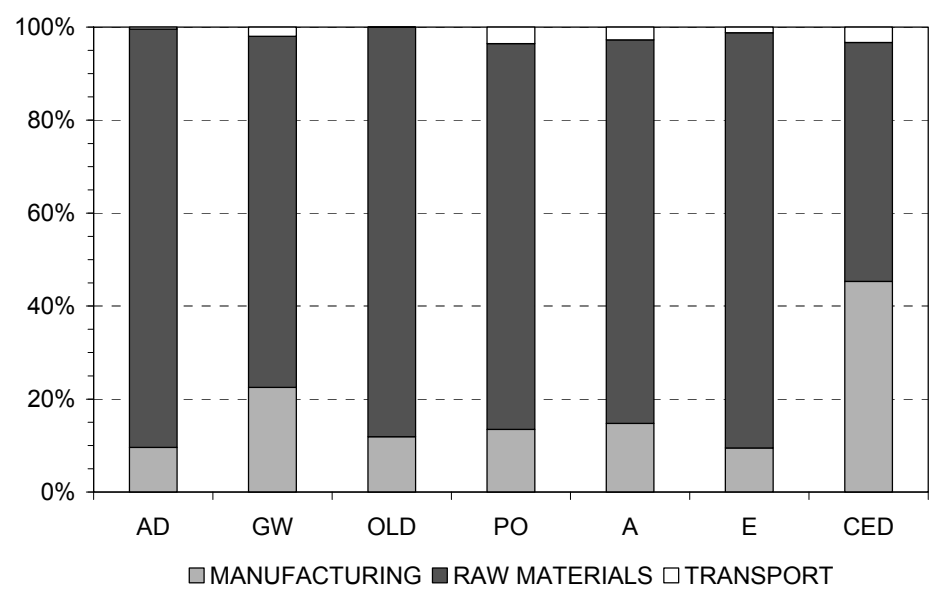

Figure 5. Contribution of FEED components to the environmental impact potentials.

Amongst the sources of protein, overall fish and soybean meal made the greatest contribution to the impact categories (Figure 6). In the case of soybean meal, this is due to its production in the field and extraction of the oil with solvents. In the case of fish meal, the cost of fuel for fishing vessels and the thermal dehydration process to obtain the meal were responsible. By contrast, wheat gluten meal and maize gluten meal made low contributions to the impact categories. Although the former (fish meal and soybean meal) are present in the feed in a greater proportion than wheat gluten meal and maize gluten meal, representing approximately double the amount, this does not explain the results (Table 2). As shown in Figure 7, the overall contribution to all potential environmental impacts of soybean meal $(20 \%)$ and fish meal (35\%) is $2-4$-times higher than that of wheat gluten meal and 3-5-times higher than for maize gluten meal. As for these last two, the contribution of the former raw material $(8 \%)$ is higher than that of the latter $(6 \%)$. Therefore, of the protein sources, maize gluten meal made the lowest contribution to environmental impacts (Figure 7). 
In agreement with several authors $[33,43,44,52,60]$, this study found that feed is the greatest contributor to most of the environmental impacts of fish farms, except eutrophication. An LCA of the feed for turbot also found that raw materials were greater contributors to environmental impact than the manufacturing processes [44]. It was also found that soybeans and fish meal were the raw materials contributing the most environmental impacts and suggested that this may be due to the fact that present day fish feeds depend on large quantities of these raw materials. A comparative assessment of feed manufacturing shows that different protein sources have different impact results [63], and the formulation of feed is the most important contributor in all production systems (extensive, intensive and recirculating) for rainbow trout [34]. The substitution of feed ingredients would be the main alternative if the environmental impacts of fish feed are to be reduced [52].

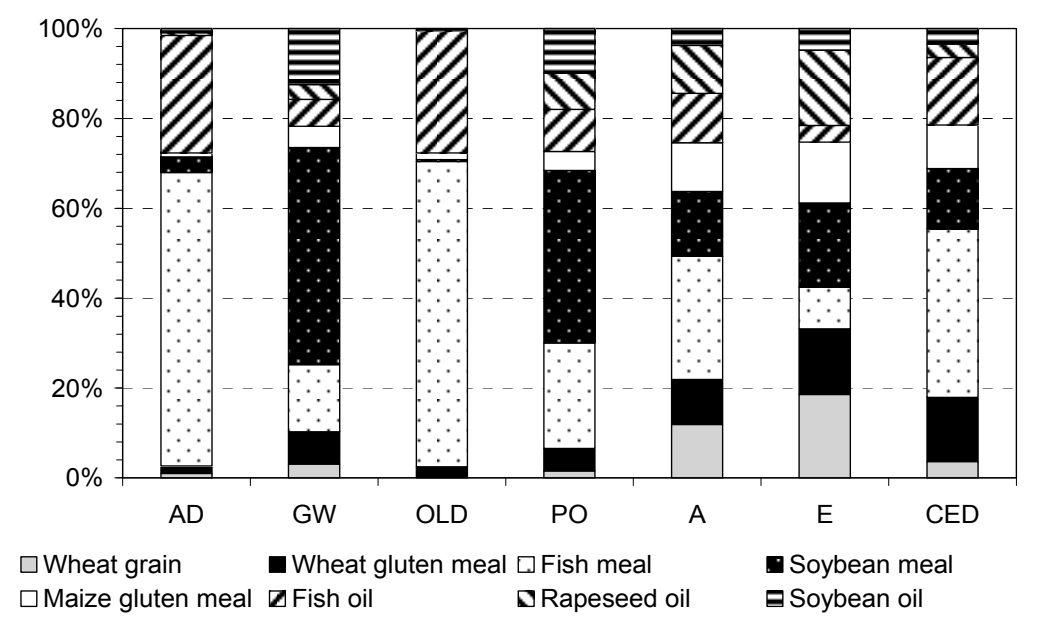

Figure 6. Contribution of RAW MATERIALS to the environmental impact potentials.

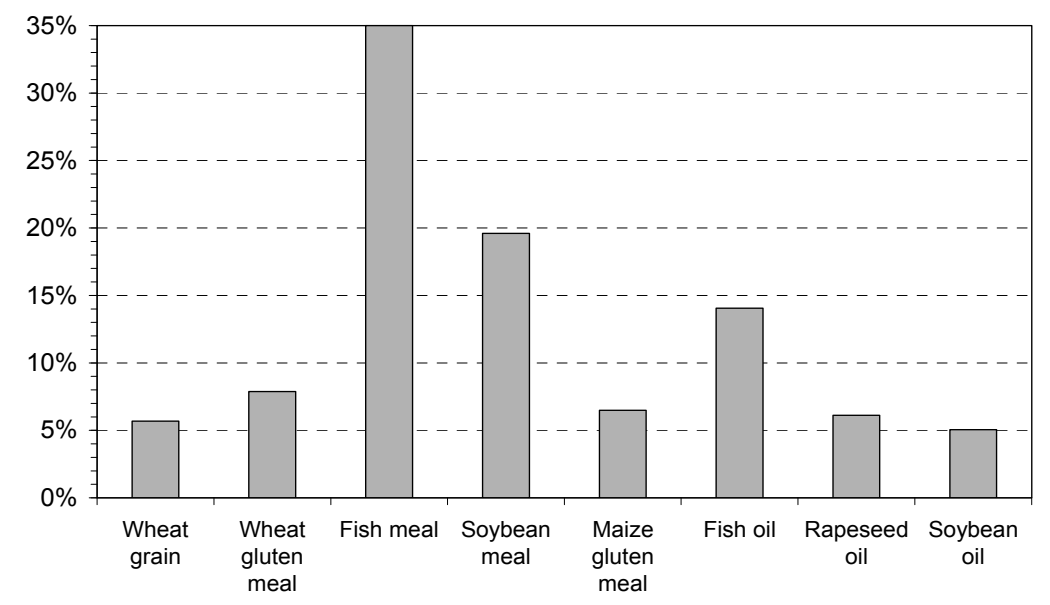

Figure 7. Overall contribution of each raw material to all potential impacts.

\subsubsection{GROWTH}

The emission of $\mathrm{N}$ estimated in this study $\left(119.59 \mathrm{~kg} \cdot \mathrm{t}^{-1}\right)$ is the highest of those calculated for other species studied and in other aquaculture systems (Table 4). Only the values for seabass are similar $[43,60]$. There was a direct relationship between the values of FCR and $\mathrm{N}$ emissions, and the value of FCR was highest in the present study. However, this relationship was not observed in the emission of $\mathrm{P}$. The estimated value here $\left(5.9 \mathrm{~kg} \cdot \mathrm{t}^{-1}\right)$, which is lower than that calculated for seabass, falls within the range of variations observed in the different studies $\left(4.1-18.1 \mathrm{~kg} \cdot \mathrm{t}^{-1}\right)$ mentioned in Table 4 .

GROWTH only contributes to E (Figure 3), although, for this particular impact category, it is the component that has the greatest weight, representing $84 \%$, while FEED only represents $11 \%$ 
(Figure 3). These results are equivalent to those found for different species and in different aquaculture systems [32-34,43,58,60]. For example, similar values of around an $80 \%$ contribution for GROWTH were found in different ongrowing systems for Atlantic salmon at sea (net-pen and floating bag) and on land (land-based flow-through). The exception was in the recirculating system, where water can be collected and treated [32].

Table 4. Acidification (A), eutrophication (E) and global warming (GW) data in the production of $1 \mathrm{t}$ live-weight according to several alternatives and values obtained in other LCA studies.

\begin{tabular}{|c|c|c|c|c|c|c|c|c|}
\hline $\begin{array}{l}\text { Aquaculture } \\
\text { System }\end{array}$ & Species & FCR & $\underset{\left(\mathrm{kg} \cdot \mathrm{t}^{-1}\right)}{\text { Output N }}$ & $\begin{array}{c}\text { Output P } \\
\left(\mathrm{kg} \cdot \mathrm{t}^{-1}\right)\end{array}$ & $\begin{array}{c}\mathrm{A}(\mathrm{kg} \\
\mathrm{SO}_{2} \text {-eq) }\end{array}$ & $\begin{array}{c}\mathrm{E}(\mathrm{kg} \\
\mathrm{PO}_{4} \text {-eq) }\end{array}$ & $\begin{array}{l}\mathrm{GW}(\mathrm{kg} \\
\mathrm{CO}_{2} \text {-eq) }\end{array}$ & Ref. \\
\hline Offshore cage & (1) & & & & & & & \\
\hline \multicolumn{9}{|l|}{ This study } \\
\hline BOFF & & 2.0 & 119.3 & 5.9 & 38.5 & 81.8 & 7124 & \\
\hline Alternative 1 & & 1.7 & 97.7 & 3.2 & 35.9 & 62.9 & 6346 & \\
\hline Alternative 2 & & 1.7 & 97.7 & 3.2 & 29.6 & 61.6 & 5769 & \\
\hline Alternative 3 & & 2.0 & 119.3 & 5.9 & 39.2 & 83.4 & 5595 & \\
\hline Alternative 4 & & 1.7 & 97.7 & 3.2 & 30.3 & 63.0 & 4484 & \\
\hline \multicolumn{9}{|l|}{ Marine system } \\
\hline Sea cage & (2) & 1.8 & 101.7 & 16.7 & 25.3 & 109.0 & 3600 & [43] \\
\hline Net-pen & (3) & 1.3 & 31.3 & 4.9 & 17.9 & 35.3 & 2073 & [32] \\
\hline Net-pen, Norway & (3) & 1.1 & 41.1 & 5.2 & 17.1 & 41.0 & 1790 & [33] \\
\hline Net-pen, UK & (3) & 1.3 & 58.7 & 8.5 & 29.7 & 62.7 & 3270 & [33] \\
\hline Net-pen, Canada & (3) & 1.3 & 51.4 & 13.6 & 28.1 & 74.9 & 2370 & [33] \\
\hline Net-pen, Chile & (3) & 1.5 & 71.3 & 12.6 & 20.4 & 51.3 & 2300 & [33] \\
\hline Floating bag & (3) & 1.2 & 28.4 & 4.4 & 18.0 & 31.9 & 2250 & [32] \\
\hline \multicolumn{9}{|l|}{ Land system } \\
\hline Raceway system & (2) & 1.8 & 107.6 & 15.0 & 54.0 & 180.0 & 11,087 & [60] \\
\hline Cascade system & (2) & 2.1 & 111.6 & 18.1 & 70.0 & 215.0 & 17,449 & [60] \\
\hline Flow-through tank & (3) & 1.2 & 26.0 & 4.1 & 33.3 & 31.0 & 5410 & [32] \\
\hline Extensive system & (4) & 1.2 & 65.0 & 10.0 & 10.7 & 60.4 & 2239 & [34] \\
\hline Intensive system & (4) & 0.9 & 65.0 & 10.0 & 10.8 & 60.0 & 3561 & [34] \\
\hline Flow-through tank & (4) & 1.2 & 65.0 & 10.0 & 19.2 & 28.5 & 2020 & [43] \\
\hline Recirculating & (5) & 1.2 & 81.5 & 10.6 & 48.3 & 77.0 & 6017 & [35] \\
\hline Recirculating $\left(^{*}\right)$ & (6) & 1.4 & 0.0 & 0.0 & 63.4 & 11.6 & 10,300 & [32] \\
\hline Recirculating $\left(^{*}\right)$ & (4) & 0.9 & 0.0 & 0.0 & 40.7 & 4.0 & 13,622 & [34] \\
\hline
\end{tabular}

\subsubsection{FUEL}

FUEL has a major impact on A (55\%), but also on CED (52\%), OLD (48\%) and PO (46\%) (Figure 3). Diesel consumption in the BOFF studied here is much higher than that recorded for marine net-pens for the ongrowing of Atlantic salmon, about $28 \mathrm{~L}$ of diesel and 36.3 of gasoline per tonne of live-weight fish [32]. This is because BOFFs are much further from the coast, about $5 \mathrm{~km}$, than net-pen structures, which usually consist of several cages around $100 \mathrm{~m}$ off the coast or in fjords for shelter from storms [64]. The cages are usually arranged in two rows along either side of a central walkway, which facilitates routine operations (review of cages, removal of casualties, feeding, etc.) without requiring workers to use boats. Furthermore, the distribution of feed is usually centralized and automated, so the boats do not have to go from one cage to another to distribute feed, as in the BOFF.

\subsection{Sensitivity Analysis}

\subsubsection{Alternative 1: FCR Sensitivity Analysis}

The FCR value affects FEED and GROWTH, with FEED being the component that contributes most to the global impact of the activity. The FCR used in this work (two) is obtained from confidential surveys of companies in the sector. High values are also found for the culture of seabass (Table 4) both in cages [43] and in tanks [60], in contrast to the low values (Table 4) reported for Atlantic salmon [32,33] and trout [34,43]. The distribution of food plays an important role in these differences; the culture of the latter species usually involves automatically-driven and programmed centralized 
feeding systems, as well as feed control systems, to minimize the feed supplied and the amount of uneaten feed.

When the distribution of food is manual, it is assumed that some is not captured and digested by the fish, and the efficiency of food seems to have a determining influence on the level of impacts related to the feeding of seabass [60]. In BOFF, feed was distributed by canon, which can be considered practically as a manual system, and, in addition, was supplied only one or two times a day, so feeding efficiency is low. In salmonids, it was reported that the feeding regime and food distribution influence the amount of feed lost in sea cages with a large number of fish [65-67].

On the other hand, seabream, unlike seabass or Atlantic salmon, chew the feed before swallowing it, and this behavior generates waste in the form of pellet fragments, which is related to their size, and can represent as much as $8.45 \%$ of the feed during the whole ongrowing cycle [68]. As the authors indicate, these losses can be minimized with a proper food supply protocol, taking into account the size of the pellet and the size of the fish, and thus, have a significant economic impact on the fish farm [69].

Losses can be minimized, as shown in the cultivation of salmonids, by developing a suitable protocol for feed supply (pellet size, frequency of distribution, etc.) and installing centralized, automatic feed control systems. In this way, the wasted feed in salmon farming fell from $20 \%-30 \%$ [70] to $3 \%$ [14].

Producers of seabream and seabass in offshore systems in the Mediterranean are aware that they have to implement centralized, automatic feed control and distribution systems to reduce the FCR. It is important to emphasize that feeding costs in this type of fish farm are $45 \%-50 \%$ of the production costs, so the loss of feed has a major economic impact. In fact, some companies have a platform or feed silo boats and mechanized distribution systems, although no generalized control systems. After consultation with several producers in the same study area [71], feed loss was estimated to be $5 \%-10 \%$ of the food provided in seabream farms. Our consultations with producers provided higher values of around $15 \%$.

Thus, a sensitivity analysis was made to evaluate the possibility of attaining an FCR of 1.7, that is reducing the losses of supplied feed by $15 \%$. In such a situation there would be a reduction in the total environmental impact (GRI) with respect to the BOFF of $10 \%$ (Table 5). The Monte Carlo analysis determined that for all categories of environmental impact, the probability that $\mathrm{A} \geq \mathrm{B}$ was $100 \%$. The most affected impact category would be E, with a reduction of $23 \%$ (Figure 8 ), although we should also highlight the reduction in GW (11\%); for the other categories, impact reduction values would be between $7 \%(A)$ and $9 \%(A D)$.
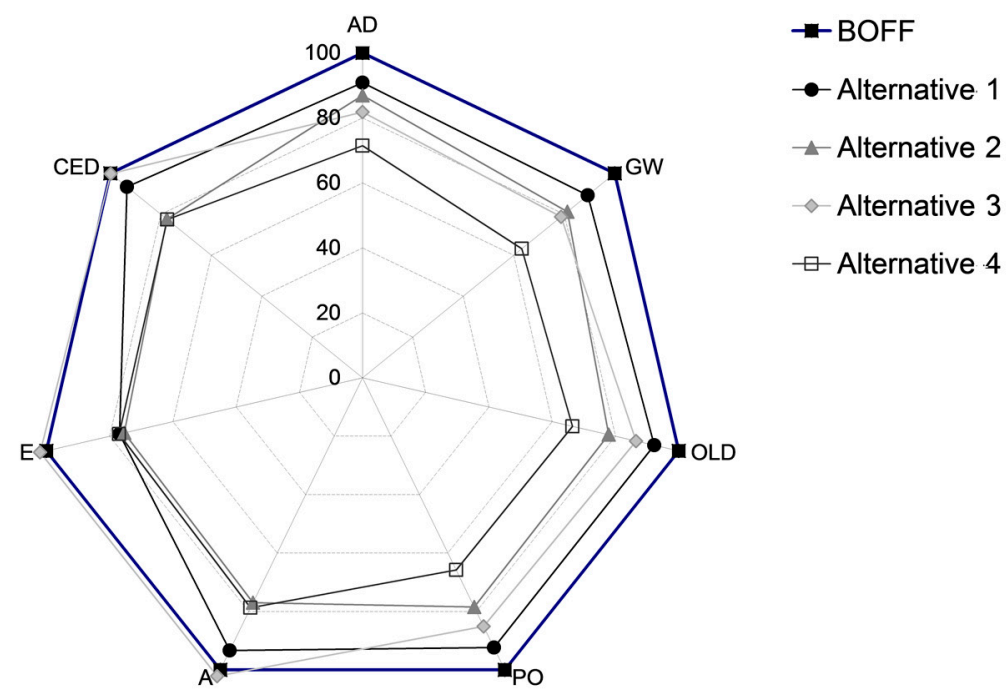

Figure 8. Comparison of potential environmental impacts between basic offshore fish farm (BOFF) and alternatives. 
Table 5. The overall contribution of each component of the system to all the impact categories (overall contribution (OC) \%).

\begin{tabular}{cccccc}
\hline Alternatives & INSTALLATION & FUEL & GROWTH & FEED & GRI \\
\hline BOFF & 4.96 & 35.23 & 11.94 & 47.87 & \\
Alternative 1 & 5.45 & 38.32 & 11.55 & 44.69 & 10.24 \\
Alternative 2 & 5.87 & 31.44 & 11.78 & 50.91 & 20.81 \\
Alternative 3 & 5.92 & 38.76 & 11.72 & 43.61 & 9.15 \\
Alternative 4 & 6.97 & 34.74 & 11.53 & 46.75 & 28.59 \\
\hline
\end{tabular}

GRI: global reduction of impacts in relation to BOFF. BOFF: standard feed, FCR 2, 100\% FUEL. Alternative 1: standard feed and FCR 1.7. Alternative 2: standard feed and FCR 1.7 and 70\% FUEL. Alternative 3: raw materials alternative ( $40 \%$ maize gluten meal) and FCR 2 . Alternative 4: raw materials alternative ( $40 \%$ maize gluten meal), FCR 1.7 and $70 \%$ FUEL.

\subsubsection{Alternative 2: Sensitivity Analysis of Fuel Consumption}

With a centralized system of feed distribution and control in the BOFF, the routine activities of the vessels would diminish significantly, with a consequent reduction in fuel consumption. The necessary infrastructure, as already shown, would not have a significant impact on potential environmental impacts. We do not have all of the data necessary to calculate how much fuel consumption could be reduced, but to analyze the impact of this factor on the environment, we have estimated a reduction of $30 \%$.

Alternative 2 gives an FCR of 1.7 and $70 \%$ of FUEL consumption, which would lead to a reduction in the overall impact of $21 \%$ (Table 5). The Monte Carlo analysis determined that for all categories of environmental impact, the probability that $\mathrm{A} \geq \mathrm{B}$ is $100 \%$. In this situation, the reduction in the different environmental impacts (Figure 8) would vary between $13 \%(\mathrm{AD})$ and $25 \%$ (E). The absolute value of GW would be higher than the reported values in net-pen systems of Atlantic salmon and would be within the range reached in land-based fish farming systems (Table 4).

\subsubsection{Alternative 3: Sensitivity Analysis for Changes in Raw Materials of Feed}

Using maize gluten meal as a source of protein in feed for fish reduces the use of marine-origin resources in the diets, lowering the environmental impact or, at least, bringing it into line with standard feeds, since the energy used to produce maize gluten meal is less than that required to produce fish meal [52]. Maize gluten meal, a protein-rich by-product of the manufacture of maize starch by the wet milling process [72], could be a good alternative for feeding seabream. Furthermore, it is low in fiber, has no anti-nutritional factors and, except for arginine, lysine and methionine, has a good essential amino acid profile. Different studies have shown that maize gluten meal is well accepted by seabream ( $40 \%$ content of the feed) and other fish species [72,73].

Based on all of this, we evaluated an alternative diet whose composition in raw materials is shown in Table 6. In short, we increased the content of maize gluten meal and omitted soybean meal, while the proportion of fish meal was reduced to $10 \%$. Given that the cost of using amino acids as feed supplement is still not clearly understood financially or environmentally, it will be necessary to carry on using a certain percentage of fishmeal [52].

The alternative diet resulted in a reduction in the global impact compared with the basic fish farm of $9 \%$ (Table 5). The Monte Carlo analysis determined that for AD, GW, OLD and PO, the probability of $\mathrm{A} \geq \mathrm{B}$ was $100 \%, 75 \%$ for $\mathrm{CED}$ and $0 \%$ for $\mathrm{A}$ and $\mathrm{E}$. The environmental impact reduction (Figure 8 ) was $18 \%$ for $\mathrm{AD}, 21 \%$ for GW, $14 \%$ for OLD and $15 \%$ for PO. These results agree with those suggested by other authors in terms of the importance of raw materials in the formulation of feed for reducing the environmental impacts of the aquaculture $[52,57,63]$. 
Table 6. Raw materials and nutritional composition in $\mathrm{kg}$ for 1 tonne of feed.

\begin{tabular}{|c|c|c|}
\hline Raw Materials $\left(\mathrm{kg} \cdot \mathrm{t}^{-1}\right)$ & Standard Feed & Alternative Feed \\
\hline Whole Wheat & 140 & 140 \\
\hline Soybean meal & 220 & \\
\hline Wheat gluten & 130 & 150 \\
\hline Corn gluten meal & 100 & 400 \\
\hline Fish meal & 200 & 100 \\
\hline Fish oil & 80 & 80 \\
\hline Soybean oil & 50 & 50 \\
\hline Rapeseed oil & 50 & 50 \\
\hline \multicolumn{3}{|c|}{ Nutritional composition $\left(\mathrm{kg} \cdot \mathrm{t}^{-1}\right)$} \\
\hline Protein & 426.55 & 453.15 \\
\hline Lipid & 220.20 & 212.60 \\
\hline Fiber & 18.57 & 9.97 \\
\hline Starch & 131.20 & 165.10 \\
\hline Ash & 39.91 & 21.54 \\
\hline Gross energy $\left(\mathrm{MJ} \cdot \mathrm{kg}^{-1}\right)$ & 22.12 & 22.98 \\
\hline Protein/Energy & 19.28 & 19.72 \\
\hline
\end{tabular}

\subsubsection{Alternative 4: All of the Above Factors}

In this alternative, the analyzed scenario includes the three previous stages, that is an FCR of 1.7, $70 \%$ FUEL and the alternative diet with $40 \%$ maize gluten meal.

The Monte Carlo analysis determined that for all categories of environmental impact, the probability of $A \geq B$ is $100 \%$. The overall impact reduction would reach $29 \%$, varying (Figure 8 ) between $21 \%(\mathrm{~A})$ and $37 \%(\mathrm{GW})$ (Table 5). In this scenario, the overall contribution of the infrastructure increases slightly $(7 \%)$, although it should be noted that most of the materials used in the installation can be recycled. Thus, suitable management of the recycling of the different materials, in particular of the metal, would be also an environmental advantage.

This scenario (Alternative 4) is perhaps the one that should be pursued by offshore fish farming companies in the Mediterranean Sea, since, in addition to environmental improvements, it represents an important reduction in the production of feed and fuel costs.

\section{Conclusions}

As described for other fish farming systems, in the offshore production of seabream, operations related to feeding - fish feed and emissions of $\mathrm{N}$ and $\mathrm{P}$ due to the metabolism of the fish-are the factors that make the greatest contribution to environmental impacts.

The establishment of protocols suitable for the feeding of seabream (optimal ration, frequency and feed supply schedule), the incorporation of technology for the centralized and automated distribution of feed, as well as control systems to prevent losses are needed to decrease FCR. This would represent a significant degree of environmental improvement both in global and local terms. These actions would not only improve the environmental image of the production companies, but would also contribute to the decrease in production costs. These recommendations might form an important line of technological research and development to ensure the sustainability of the offshore aquaculture sector.

Feed formulation is also seen as an important research line in order to incorporate raw materials that involve the lowest environmental costs possible, while maintaining production (growth, survival and FCR) and financial returns.

Although in general, it makes a low contribution to environmental impacts, the infrastructure should also be taken into account, and it is important to establish mechanisms for recycling as many components as possible. 
Acknowledgments: The research project FEDER 14-20-09 is funded $80 \%$ by the European Regional Development Fund, "One way to make Europe".

Author Contributions: The four authors conceived of and designed the present study. The role of each of the authors was as follows: foreground data (installation, fuel, emissions $\mathrm{N}$ and $\mathrm{P}$, and feed) were collected by José García García and Felipe Aguado Giménez; background data (Ecoinvent and Agri-footprint databases) and LCA with SimaPro were collected by Caridad Rosique Jiménez and Benjamín García García; all four authors drafted the manuscript.

Conflicts of Interest: The authors declare no conflict of interest.

\section{References}

1. Basurco, B.; Lovatelli, A.; García García, B. Current status of Sparidae aquaculture. In Sparidae. Biology and Aquaculture of Gilthead Sea Bream and Other Species; Pavlidis, M.A., Mylonas, C.C., Eds.; Blackwell Publishing Ltd.: Oxford, UK, 2011; pp. 1-50.

2. Apromar Asociación Empresarial de Productores de Cultivos Marinos. La Acuicultura en España; Ministerio de Agricultura, Alimentación y Medioambiente, Gobierno de España: Madrid, Spain, 2015.

3. Ruiz, J.M.; Pérez, M.; Romero, J. Effects of fish farm loading on seagrass (Posidonia oceanica) distribution, growth and photosynthesis. Mar. Pollut. Bull. 2001, 42, 749-760. [CrossRef]

4. Cancemi, G.; De Falco, G.; Pergent, G. Effects of organic input from a fish farming facility on a Posidonia oceanica meadow. Estuar. Coast. Shelf Sci. 2003, 56, 961-968. [CrossRef]

5. Holmer, M.; Pérez, M.; Duarte, C. Benthic primary producers: A neglected environmental problem in Mediterranean mariculture? Mar. Pollut. Bull. 2003, 46, 1372-1376. [CrossRef]

6. Aguado-Giménez, F.; Ruiz, J.M. Influence of an experimental fish farm on the spatio-temporal dynamic of a Mediterranean Maërl algae community. Mar. Environ. Res. 2012, 74, 47-55. [CrossRef] [PubMed]

7. Baez Paleo, J.D. Ingeniería de la Acuicultura Marina: Instalaciones de Peces en el Mar; Publicaciones Científicas y Tecnológicas de la Fundación OESA: Madrid, Spain, 2009.

8. Hargrave, B.T.; Duplisea, D.E.; Pfeiffer, E.; Wildish, D.J. Seasonal changes in benthic fluxes of dissolved oxygen and ammonium associated with marine cultured Atlantic salmon. Mar. Ecol. Prog. Ser. 1993, 96, 249-257. [CrossRef]

9. Hargrave, B.T.; Holmer, M.; Newcombre, C.P. Towards a classification of organic enrichment in marine sediments based on biogeochemical indicators. Mar. Pollut. Bull. 2008, 56, 810-824. [CrossRef] [PubMed]

10. Lupatsch, Y.; Kissil, G.W. Predicting aquaculture waste from gilthead seabream (Sparus aurata) culture using a nutritional approach. Aquat. Living Resour. 1998, 11, 265-268. [CrossRef]

11. Karakassis, I.; Hatziyanni, E.; Tsapakis, M.; Plaiti, W. Benthic recovery following cessation of fish farming: A series of sucesses and catastrophes. Mar. Ecol. Prog. Ser. 1999, 184, 205-218. [CrossRef]

12. Mazzola, A.; Mirto, S.; La Rosa, T.; Fabiano, M.; Danovaro, R. Fish farming effects on benthic community structure in coastal sediments: Analysis of meiofaunal resilience. ICES J. Mar. Sci. 2000, 57, 1454-1461. [CrossRef]

13. Black, K.D. Sustainability of aquaculture. In Environmental Impacts of Aquaculture; Black, K.D., Ed.; Sheffield Academic Press: Sheffield, UK, 2001; pp. 199-212.

14. Cromey, C.J.; Nickell, T.D.; Black, K.D. DEPOMOD-modeling the deposition and biological effects of waste solids from marine cage farm. Aquaculture 2002, 214, 211-239. [CrossRef]

15. Aguado-Giménez, F.; García García, B.; Martínez, F.J. In vivo total nitrogen and total phosphorus digestibility in Atlantic Bluefin tuna (Thunnus thynnus) under industrially intensive fattening conditions in Sutheast Spain Mediterranean coastal waters. Aquac. Nutr. 2004, 10, 413-419. [CrossRef]

16. Piedecausa, M.A.; Aguado-Giménez, F.; García García, B.; Telfer, T. Total ammonia nitrogen leaching from feed pellets used in salmon aquaculture. J. Appl. Ichthyol. 2010, 26, 16-20. [CrossRef]

17. Cho, C.Y.; Hynes, J.D.; Wood, K.R.; Yoshida, H.K. Quantification of fish culture wastes by biological (nutritional) and chemical (limnological) methods: The development of high nutrient dense (HND) diets. In Nutritional Strategies and Aquaculture Waste; Cowey, C.B., Cho, C.Y., Eds.; University of Guelph: Guelph, ON, Canada, 1991; pp. 37-50.

18. Aguado-Giménez, F.; García García, B.; Hernádez, M.D.; Cerezo Valverde, J. Gross metabolic waste output estimates using a nutritional approach in Atlantic bluefin tuna (Thunnus thynnus) under intensive fattening conditions in western Mediterranean Sea. Aquac. Res. 2006, 37, 1254-1258. [CrossRef] 
19. Pitta, P.; Karakassis, I.; Tsapakis, M.; Zivanovic, S. Natural vs. Mariculture induced variability in nutrients and plankton in the Eastern Mediterranean. Hydrobiologia 1999, 391, 181-184.

20. Pitta, P.; Apostolaki, E.T.; Giannoulaki, M.; Karakassis, I. Mesoscale changes in the water column in response to fish farming zones in three coastal areas in the Eastern Mediterranean Sea. Estuar. Coast. Shelf Sci. 2005, 65, 501-512. [CrossRef]

21. Pitta, P.; Tsapakis, M.; Apostolaki, E.T.; Tsagaraki, T.; Holmer, M.; Karakassis, I. "Ghost nutrients" from fish farms are transferred up the food web by phytoplankton grazers. Mar. Ecol. Prog. Ser. 2009, 374, 1-6. [CrossRef]

22. Thigstad, T.F.; Krom, M.D.; Mantoura, R.F.C.; Flaten, G.A.G.; Groom, S.; Herut, B.; Kress, N.; Law, C.S.; Pasternak, A.; Pitta, P.; et al. Nature of phosphorous limitation in the ultraoligotrophic eastern Mediterranean. Science 2005, 309, 1068-1071. [CrossRef] [PubMed]

23. Karakassis, I.; Tsapakis, M.; Hatziyanni, E.; Papadopoulou, K.N. Impact of cage farming of fish on the seabed in three Mediterranean coastal areas. ICES J. Mar. Sci. 2000, 57, 1462-1471. [CrossRef]

24. Aguado-Giménez, F; García García, B. Assessment of some chemical parameters in marine sediments exposed to offshore cage fish farming influence: A pilot study. Aquaculture 2004, 242, 283-296. [CrossRef]

25. Kalantzi, I.; Karakassis, I. Benthic impacts of fish farming: Meta-analysis of community and geochemical data. Mar. Pollut. Bull. 2006, 52, 484-493. [CrossRef] [PubMed]

26. Aguado-Giménez, F.; Marín, A.; Montoya, S.; Marín-Guirao, L.; Piedecausa, M.A.; García García, B. Comparison between some procedures for monitoring offshore cage culture in western Mediterranean Sea: Sampling methods and impact indicators in soft substata. Aquaculture 2007, 271, 357-370. [CrossRef]

27. Aguado-Giménez, F.; Piedecausa, M.A.; Carrasco, C.; Gutiérrez, J.M.; Aliaga, V.; García García, B. Do benthic biofilters contribute to sustainability and restoration of the benthic environment impacted by offshore cage finfish aquaculture? Mar. Pollut. Bull. 2011, 62, 1714-1724. [CrossRef] [PubMed]

28. Marín, A.; Montoya, S.; Vita, R.; Marín-Guirao, L.; Lloret, J.; Aguado-Giménez, F. Utility of sea urchin embryo-larval bioassays for assessing the environmental impact of marine fishcage farming. Aquaculture 2007, 271, 286-297. [CrossRef]

29. Piedecausa, M.A.; Aguado-Giménez, F.; Cerezo Valverde, J.; Hernández, M.D.; García García, B. Simulating the temporal pattern of waste production in farmed gilthead seabream (Sparus aurata), European seabass (Dicentrarchus labrax) and Atlantic bluefin tuna (Thunnus thynnus). Ecol. Model. 2010, 221, 634-640. [CrossRef]

30. Piedecausa, M.A.; Aguado-Giménez, F.; Cerezo Valverde, J.; Hernádez, M.D.; García García, B. Influence of fish food and faecal pellets on short-term oxygen uptake, ammonium flux and acid volatile sulphide accumulation in sediments impacted by fish farming and non-impacted sediments. Aquac. Res. 2012, 43, 66-74. [CrossRef]

31. Fernández-González, V.; Aguado-Giménez, F.; Gairin, J.I.; Sánchez-Jerez, P. Exploring patterns of variation in amphipod assemblages at multiple spatial scales: Natural variability versus coastal aquaculture effect. Aquac. Environ. Interact. 2013, 3, 93-105. [CrossRef]

32. Ayer, N.W.; Tyedmers, P.H. Assesing alternative aquaculture technologies: Life cycle assessment of salmonid culture systems in Canada. J. Clean. Prod. 2009, 17, 362-373. [CrossRef]

33. Pelletier, N.; Tyedmers, P.; Sonesson, U.; Scholz, A.; Ziegler, F.; Flysjo, A.; Kruse, S.; Cancino, B.; Silverman, H. Not all salmon are created equal: Life cycle assessment (LCA) of global salmon farming systems. Environ. Sci. Technol. 2009, 43, 8730-8736. [CrossRef] [PubMed]

34. Samuel-Fitwi, B.; Nagel, F.; Meyer, S.; Schroeder, J.P.; Schulz, C. Comparative life cycle assessment (LCA) of raising rainbow trout (Oncorhynchus mykiss) in different production systems. Aquac. Eng. 2013, 54, 85-92. [CrossRef]

35. Aubin, J.; Papatryphon, E.; Van der Werf, H.M.G.; Petit, J.; Morvan, Y.M. Characterisation of the environmental impact of a turbot (Scophthalmus maximus) re-circulating production system using Life Cycle Assessment. Aquaculture 2006, 261, 1259-1268. [CrossRef]

36. Bermúdez, L.; García García, B.; Ortega, A. Experiencias de engorde de dorada (Sparus aurata L.) en estanques. Cuad. Marisq. Publicaciones Téc. 1987, 8, 105-116.

37. Navarro, J.M.; Belmonte, A. Cultivo de seriola en jaulas flotantes en la bahía de "El Hornillo" (Murcia, SE España). Cuad. Marisq. Publicaciones Téc. 1987, 12, 11-16. 
38. International Organization for Standardization. ISO 14040:2006 Environmental Management-Life Cycle Assessment: Principles and Framework; International Organization for Standardization (ISO): Geneva, Switzerland, 2006.

39. International Organization for Standardization. ISO 14044:2006 Environmental Management-Life Cycle Assessment: Requirements and Guidelines; International Organization for Standardization (ISO): Geneva, Switzerland, 2006.

40. Guinée, J.B.; Gorrée, M.; Heijungs, R.; Huppes, G.; Kleijn, R.; de Koning, A.; van Oers, L.; Wegener Sleeswijk, A.; Suh, S.; Udo de Haes, H.A.; et al. Handbook on Life Cycle Assessment. Operational Guide to the ISO Standards. I: LCA in Perspective. IIa: Guide. IIb: Operational Annex. III: Scientific Background; Kluwer Academic Publishers: Dordrecht, The Netherlands, 2002.

41. Henriksson, P.J.G.; Guinée, J.B.; Kleijn, R.; de Snoo, G.R. Life cycle assessment of aquaculture systems-a review of methodologies. Int. J. Life Cycle Assess. 2012, 17, 304-313. [CrossRef] [PubMed]

42. Cao, L.; Diana, J.S.; Keoleian, G.A. Role of life cycle assessment in sustainable aquaculture. Rev. Aquac. 2013, 5, 61-71. [CrossRef]

43. Aubin, J.; Papatryphon, E.; Van der Werf, H.M.G.; Chatzifotis, S. Assesment of the environmental impact of carnivorous finfish production systems using life cycle assessment. J. Clean. Prod. 2009, 17, 354-361. [CrossRef]

44. Iribarren, D.; Moreira, M.T.; Feijoo, G. Life Cycle Assessment of Aquaculture Feed and Application to the Turbot Sector. Int. J. Env. Res. 2012, 6, 837-848.

45. Frischknecht, R.; Althaus, H.J.; Bauer, C.; Doka, G.; Heck, T.; Jungbluth, N.; Kellenberger, D.; Nemecek, T. The environmental relevance of capital goods in life cycle assessments of products and services. Int. J. Life Cycle Assess. 2007, 12, 7-17.

46. García García, J.; Rouco Yañez, A.; García García, B. Directrices generales de diseño de explotaciones de engorde de especies acuícolas en jaulas en mar. Arch. Zootec. 2002, 51, 469-472.

47. García García, J.; Rouco Yañez, A.; García García, B. Economía de escala en las explotaciones de engorde de dorada (Sparus aurata) en jaulas flotantes en el Mediterráneo. An. Vet. 2005, 21, 69-76.

48. Gasca-Leyva, E.; León, C.; Hernádez, J.M.; Vergara, J.M. Bioeconomic analysis of production location of sea bream (Sparus aurata) cultivation. Aquaculture 2005, 213, 219-232. [CrossRef]

49. Merinero, S.; Martínez, S.; Tomás, A.; Jover, M. Análisis económico de alternativas de producción de Dorada en jaulas marinas en el litoral Mediterráneo español. Rev. Aquat. 2005, 23, 1-19.

50. Aguado-Giménez, F.; García García, B.; Ballester, R.; Vicente, M. Identificación de zonas potencialmente aptas para los cultivos marinos en jaulas flotantes: Una aproximación a la ordenación de la acuicultura en la Región de Murcia. In Proceedings of the VIII Congreso Nacional de Acuicultura: Acuicultura y Desarrollo Sostenible, Santander, Spain, 22-25 May 2001.

51. Klein, J.; Geilenkirchen, G.; Hulskotte, J.; Ligterink, N.; Fortuin, P.; Mlnár-in't Veld, H. Methods for Calculating Transport Emission in The Netherland. 2014. Available online: http://www.pbl.nl/en/publications/ methods-for-calculating-transport-emissions-in-the-netherlands-2014 (accessed on 30 May 2016).

52. Boissy, J.; Aubin, J.; Drissi, A.; Van der Werf, H.M.G.; Bell, G.J.; Kaushik, S.J. Environmental impacts of plant-based salmonid diets at feed and farm scales. Aquaculture 2011, 321, 61-70. [CrossRef]

53. Cho, C.Y.; Bureau, D. Development of bioenergetic models and the Fish-PrFEQ software to estimate production feeding ration and waste output in aquaculture. Aquat. Living Resour. 1998, 11, 199-210. [CrossRef]

54. Leung, K.M.I.; Chu, J.C.W.; Wu, R.S.S. Nitrogen budgets for the aerolated grouper Epinephelus areolatus, cultured under laboratory conditions and in open-sea cages. Mar. Ecol. Prog. Ser. 1999, 186, 271-281. [CrossRef]

55. Mazón, M.J.; Piedecausa, M.A.; Hernádez, M.D.; García García, B. Evaluation of environmental nitrogen and phosphorus contributions as a result of intensive ongrowing of common octopus (Octopus vulgaris). Aquaculture 2007, 266, 226-235. [CrossRef]

56. Baez Paleo, J.D.; Villarroel Robinson, M.; Cárdenas, S. Estudio de la digestibilidad de los piensos comerciales desponibles para dorada (Sparus aurata). In Proceedings of the XII Congreso Nacional de Acuicultura: Con la Acuicultura Alimentamos Tu Salud, Madrid, Spain, 24-26 November 2009; Isabel López López: Madrid, Spain, 2009; pp. 158-159.

57. Pelletier, N.; Tyedmers, P. Feeding farmed salmon: Is organic better? Aquaculture 2007, 272, $399-416$. [CrossRef] 
58. Roque d'Orbcastel, E.; Blancheton, J.P.; Aubin, J. Towards environmentally sustainable aquaculture: Comparison between two trout farming systems using Life Cycle Assessment. Aquac. Eng. 2009, 40, 113-119. [CrossRef]

59. Iribarren, D.; Moreira, M.T.; Feijoo, G. Life Cycle Assessment of fresh and canned mussel processing and consumption in Galicia (NW Spain). Resour. Conserv. Recycl. 2010, 55, 106-117. [CrossRef]

60. Jerbi, M.A.; Aubin, J.; Achour, L.; Kacem, A. Life cycle assessment (LCA) of two rearing techniques of sea bass (Dicentrarchus labrax). Aquac. Eng. 2012, 46, 1-9. [CrossRef]

61. Avadí, A.; Fréon, P. Life cycle assessment of fisheries: A review for fisheries scientists and managers. Fish. Res. 2013, 143, 21-38. [CrossRef]

62. Cooper, J.; Diesburg, S.; Babej, A.; Noon, M.; Kahn, E.; Puettmann, M.; Colt, J. Life Cycle Assessment of products from Alaskan salmon processing wastes: Implication of coproduction, intermittent landings, and storage time. Fish. Res. 2014, 151, 26-38. [CrossRef]

63. Samuel-Fitwi, B.; Meyer, S.; Reckmann, K.; Schroeder, J.P. Aspiring for environmentally conscious aquafeed: comparative LCA of aquafeed manufacturing using different protein sources. J. Clean. Prod. 2013, 52, 225-233. [CrossRef]

64. Tyedmers, P.H. Salmon and Sustainability: The Biophysical Cost of Producing Salmon through the Comercial Salmon Fishery and the Intensive Salmon Culture Industry. Ph.D. Thesis, University of British Columbia, Vancouver, BC, Canada, 2000.

65. Ang, K.P.; Petrell, R.J. Pellet watage, and subsurface and surface feeding behaviours associated with different feeding systems in sea cage farming of salmonids. Aquac. Eng. 1998, 18, 95-115. [CrossRef]

66. Noble, C.; Kadris, S.; Mitchell, D.F.; Huntingford, F.A. Influence of feeding regime on intraspecific competition, fin damage and growth in 1+ Atlantic salmo parr (Salmo salar L.) held in freshwater production cages. Aquac. Res. 2007, 38, 1137-1143. [CrossRef]

67. Noble, C.; Mizusawa, K.; Suzuki, K.; Tabata, M. The effect of differing self-feeding regimes on the growth, behaviour and fin damage of rainbow trout held in groups. Aquaculture 2007, 264, 214-222. [CrossRef]

68. Ballester-Molto, M.; García García, B.; García García, J.; Cerezo Valverde, J.; Aguado-Giménez, F. Controlling feed losses by chewing in gilthead sea bream (Sparus aurata) ongrowing may improve the environmental sustainability of the aquacultural activity. Aquaculture 2016, 464, 111-116. [CrossRef]

69. Navas, J.I.; Cordero, M.L.; Cárdenas, S. El control de las pérdidas de alimento por la masticación en engorde de dorada (Sparus aurata) mediante regímenes alternativos basados en la gestión del tamaño de los pellets puede mejorar la rentabilidad del cultivo. In Proceedings of the XV Congreso Nacional y I Congreso Ibérico de Acuicultura: Acuicultura, Cultivando el Futuro, Huelva, Spain, 13-16 October 2015; IFAPA y SEA: Huelva, Spain, 2015; pp. 622-623.

70. Gowen, R.; Bradbury, N. The ecological impact of salmon farming in coastal waters: A review. Oceanogr. Mar. Biol. Annu. Rev. 1987, 25, 563-575.

71. Piedecausa, M.A.; Aguado-Giménez, F.; García García, B.; Ballester, G.; Telfer, T. Settling velocity and total ammonia nitrogen leaching from commercial feed and faecal pellets of gilthead seabream (Sparus aurata $\mathrm{L}$. 1758) and seabass (Dicentrarchus labrax L. 1758). Aquac. Res. 2009, 40, 1703-1714. [CrossRef]

72. Pereira, T.G.; Oliva-Teles, A. Evaluation of corn gluten meal as a protein source in diets for gilthead sea bream (Sparus aurata L.) juveniles. Aquac. Res. 2003, 34, 1111-1117. [CrossRef]

73. Robaina, L.; Moyano, F.J.; Izquierdo, M.S.; Socorro, J.; Vergara, J.M.; Montero, D. Corn gluten and meat and bone meals as protein sources in diets for gilthead seabream (Sparus aurata): Nutritional and histological implications. Aquaculture 1997, 157, 347-359. [CrossRef]

(C) 2016 by the authors; licensee MDPI, Basel, Switzerland. This article is an open access article distributed under the terms and conditions of the Creative Commons Attribution (CC-BY) license (http://creativecommons.org/licenses/by/4.0/). 